tions apparent in one of them; and Mr. Rockhill, who wrote a report on them in detail, adds, that the kind of Sanskrit text which they exhibit appears to be the only one now obtainable in and about the Chinese capital. He hoped, however, to ascertain later on whether there was not something of interest to be discovered at Wu t'ai shan, the oldest sanctuary in Northern China.

An interesting letter from Protap Chandra Roy, dated Calcutta, July 17, 1886, was read; and a scheme of the Rev. Stuart Dodge submitted for founding a School of Biblical Archæology and Philology in the East. Beirut is looked upon us the probable locality of the proposed Institution.

The following is a list of the papers read or accepted for reading :-

1. On the Syriac Part of the Chinese Nestorian Tablet, by Professor I. H. Hall.

2. On a newly discovered Syriac Manuscript, by the same. ${ }^{1}$

3. Some Arabic Proverbs; collected by Mr. James Richard Jewett, now in Syria.

4. Two Hymns of the Atharva Veda, by Professor Bloomfield, of Baltimore.

5. Observations on the Condition of Hindu Women according to the Mahābhārata, by Professor Edward W. Hopkins.

6. On Avestan Similes. I. Similes from the Realm of Nature, by Dr. A. V. Williams Jackson.

7. On a Modern Nestorian MS. Ecclesiastical Calendar, by Professor I. H. Hall.

\title{
III. Correspondence.
}

1. The Persian for Rouble.

$\mathrm{SrR},-$ The Elms, Brook Green, 16th February, 1887.

Dr. Redhouse's letter in your last issue tells us about the word used in Persian for the silver rouble (MaNás); but I imagine that it would be still more interesting could we trace the ordinary word used in that country for the paper rouble IsKeñ̄s. I do not

1 The description of this MS. given in the American Society's Record cannot fail to be interesting to all who seek information on the history of the Nestorian (or Assyrian) Church. Its Syriac title is thus translated: "History of Mar Yawallaha (or in Jacobite, Yaballaha), Catholic (Patriarch) of the East, and of Rabban Sauma, General Bishop (or Deputy General, or Vicar General)." Although there is no date or name of author attached, the latest date referred to in the MS. is November 15, 1629, of the Seleucid era=A.D. 1817. 
know where that comes from, and, although I have made many inquiries, was unable in Persia to trace its derivation.

Yours faithfully,

The Secretary of the Royal Asiatic Society.

Alexander FinN.

\section{Notes on Persian Literature from Tehran.}

10 th February, 1887.

Since writing my note on Rezá Qulí Khán and his works, further details concerning some of that author's literary productions have reached me as follows: The Latáif ul-'Árifín is a Súfí tract in prose mixed with verse. The Rfáz ul-'Arifín is divided into a Muqadimmeh, called a "Hadíqeh," two "Rózehs" and a "Ferdós"; concluding with a Khátimeh, called a "Khuld." The Khuld contains a biography of the author. I hope to be able shortly to announce the publication here, in lithograph, of this biography of the Súfís.

The Fehras ut-Taváríkh, a chronology of general Asiatic History, appears to have been lost, save that portion which was lithographed at Tabríz in A.H. 1280, but which has never been distributed. It may here be noted that the "Muntazem Násirí" of Muhammed Hasan Khán, Saní ud-Dowleh, Marághi, which is a Chronology of Historical Events in Asia from A.H. 1 to 1300, and which was issued in lithograph in three folios in A.H. 1298, 1299, and 1300 as a Year Book, is a very similar production. Volumes I. and II. of the "Muntazem Násiri" are taken up with general events; to each of these volumes a supplement is added, recording the events of the current year. Volume III. is devoted entirely to the Chronology of the Qájár dynasty. Volume II. contains a translation of a contemporary memoir on the Fall of the Sefávís, originally written in Latin, in the reign of Sháh Sultán Husain Sefáví, by a European who had spent twenty-six years at Isfahán. This memoir was translated into Ottoman Turkish by Ibráhím, and entitled "'Ibrát Námeh." The Persian version is by 'Abd urRazzáq Beg, author of the Persian original of Harford-Brydges' "Dynasty of the Kájárs." The same volume also contains an extract from Mírzá 'Abd un-Nebí Behbehânís "Táríkh Afghání," also a contemporary record of the Afghan invasion of Persia.

The works of 'Ubaid Lakání, edited by M. Ferté of the French Embassy at Constantinople, and printed in the clear and elegant type of the Abú az-Ziá press at Constantinople-for private circulation only-have just appeared in one volume, dated 1303 A.H. 